\title{
KELAYAKAN FINANSIAL USAHA BUDIDAYA IKAN BANDENG DAN NILA SISTEM KERAMBA JARING APUNG (STUDI KASUS DI PERAIRAN WADUK CIRATA, KABUPATEN CIANJUR - JAWA BARAT)
}

\author{
Zahri Nasution*), Rudhy Gustiano“) dan Yanti Suryanti“")
}

\begin{abstract}
ABSTRAK
Sejak tahun 1994, ikan bandeng yang asli dari daerah pantai dan laut mulai diusahakan masyarakat di Waduk Cirata. Untuk mengetahui kelayakan finansial usaha budidaya ikan bandeng dalam Keramba Jaring Apung (KJA) di Waduk Cirata telah dilakukan suatu penelitian yang berlangsung pada bulan Agustus 2004. Penelitian ini menggunakan pendekatan Rapid Rural Appraisal dan wawancara dengan pembudidaya ikan bandeng. Topik data yang berhubungan dengan aspek teknis dan ekonomi usaha menjadi panduan lapangan dalam pengumpulan data primer. Data yang didapatkan dianalisis menggunakan pendekatan perhitungan keuntungan usaha, nilai titik impas, dan jangka waktu pengembalian investasi. Hasil penelitian menunjukkan bahwa usaha budidaya ikan bandeng sistem KJA di perairan Waduk Cirata memberikan keuntungan usaha sebesar Rp.9.835.000.- per unit usaha menggunakan empat keramba per periode pemeliharaan selama 6 bulan. Investasi usaha yang diperlukan untuk usaha ini mencapai Rp.38.500.000.- dengan nilai titik impas dicapai pada saat produksi ikan mencapai $1.283,82 \mathrm{~kg}$ dan jangka waktu pengembalian investasi paling cepat selama 18 bulan atau 3 periode pemeliharaan. Ditinjau dari beberapa indikator kelayakan ekonomi, usaha ini hanya layak dikembangkan oleh pengusaha, bukan di tingkat pembudidaya ikan yang bermodal kecil.
\end{abstract}

ABSTRACT: Financial feasibility of milkfish culture in floating net cage (a case study at the Cirata Reservoir, Cianjur Regency of West Java Province). By: Zahri Nasution, Rudhy Gustiano and Yanti Suryanti

Since 1994, milkfish, whose natural habit is coastal to marine water, has been cultured in floating net cage system at the Cirata Reservoir. To asses the financial feasibility of this culture, a research activity has been carried out in August 2004. The primary approach of data collection is the Rapid Rural Appraisal technique and interviews with milkfish fish farmers at the reservoir. In this case, topical data corresponding to the economic and technical aspects of the aquaculture were used as a guidance. Data obtained were financially analyzed in terms of profitability, break even point, and pay back period. Results of research show that milkfish aquaculture at Cirata Reservoir can generate profits of Rp.9.835.000.- per culture unit consisting of four floating net cages per 6 months. Total invesment required to initiate this aquaculture is Rp 38.500.000.- Break even point is found to be $1.283,82 \mathrm{~kg}$ while the pay back period is 18 months or 3 culture periods. These financial indicators suggest that milkfish culture is feasible for big operator, but not for small scale ones.

KEYWORDS: financial feasibility, milkfish, cage culture, Cirata Reservoir, West Java

\section{PENDAHULUAN}

Dewasa ini, perairan waduk dan danau di Indonesia mencapai 2,6 juta hektar (Sarnita, 1986), diantaranya banyak yang berfungsi sebagai lahan untuk usaha budidaya ikan. Beberapa tahun terakhir, terjadi kecenderungan penurunan luas danau di beberapa daerah. Di sisi lain luas perairan waduk semakin bertambah karena adanya pembangunan waduk-waduk baru. Oleh karena itu, peranan waduk sebagai penyedia lahan bagi usaha budidaya menggunakan Keramba Jaring Apung (KJA) akan semakin meningkat di masa mendatang.
Secara umum perkembangan KJA yang pesat berdampak positip terhadap peningkatan produksi ikan air tawar dan pendapatan petani ikan. Namun demikian, peningkatan jumlah unit KJA yang kurang terkendali telah menimbulkan berbagai masalah yang berdampak negatip, baik secara ekonomi maupun terhadap lingkungan perairan. Dampak yang lebih besar, dapat mengganggu kelangsungan pembangkit listrik. Hal tersebut dapat disebabkan oleh limbah KJA di perairan waduk yang berupa sisa pakan dan kotoran ikan yang masuk ke perairan.

Beberapa hasil studi telah menunjukkan bahwa kelebihan jumlah KJA dari daya dukung perairan

\footnotetext{
") Peneliti pada Pusat Riset Pengolahan Produk dan Sosial Ekonomi Kelautan dan Perikanan

-) Peneliti pada Balai Riset Perikanan Budidaya Air Tawar, Pusat Riset Perikanan Budidaya
} 
mengakibatkan kelebihan jumlah sisa pakan dan kotoran ikan yang harus diterima oleh perairan waduk. Limbah tersebut akan mengakibatkan pengkayaan unsur hara $\mathrm{N}$ dan $\mathrm{P}$ yang akan meningkatkan proses penyuburan perairan (eutrofikasi) dan akan menimbulkan "blooming" fitoplankton (Kartamiharja, 1995; Krismono \& Krismono, 1998). Akibat dari ketidakseimbangan bahan organik yang berlimpah akan menyebabkan terjadi kematian ikan yang dipelihara sebagai konsekuensi dari menurunnya kualitas perairan. Hasil perhitungan pakan yang terbuang dalam pelaksanaan budidaya ikan sistem KJA di perairan Waduk Saguling mengakibatkan kerugian secara ekonomi sebesar 1.830,65 ton $x$ Rp.2.000,- per kg atau sama dengan sebesar Rp.3.661.300.000,- (lebih dari Rp.3,6 milyar) per tahun (Nasution, 1999).

Jenis ikan yang banyak diusahakan oleh pembudidaya ikan di perairan Waduk Cirata adalah ikan mas, nila dan patin. Pengusahaan ketiga komoditas tersebut telah menjadi suatu usaha yang bersifat komersil. Usaha pemeliharaannya dilakukan menggunakan jaring ganda ataupun tunggal. Dalam perkembangan budidaya ikan dalam sistem KJA di perairan waduk, mulai dekade yang lalu telah berkembang pula pemeliharaan ikan bandeng.

Adanya jenis ikan bandeng dalam usaha budidaya ikan sistem KJA di perairan Waduk Cirata, diharapkan dapat menambah sumber penghasilan pembudidaya ikan di waduk ini. Penelitian ini bertujuan untuk menganalisa kelayakan finansial usaha budidaya ikan bandeng dalam sistem KJA di Waduk Cirata. Sejauh mana usaha budidaya ikan bandeng yang dipelihara dengan sistem KJA di perairan Waduk Cirata ini memberikan keuntungan dan dapat dipertimbangkan sebagai suatu usaha yang berkelanjutan dan mempunyai prospek untuk dikembangkan akan dibahas dalam tulisan ini. Dari hasil anaiisa yang dilakukan diharapkan dapat memberikan masukan untuk menentukan arah kebijakan dari pemerintah setempat dalam rangka mengoptimalkan fungsi waduk dan sekaligus meningkatkan kesejahteraan pembudidaya ikan di wilayah tersebut.

\section{METODE}

Penelitian ini bersifat penelitian di lapangan dalam bentuk pengumpulan data primer pada beberapa informan kunci maupun pembudidaya ikan bandeng di wilayah Waduk Cirata, lokasi Jangari, Kabupaten Cianjur, Jawa Barat.

Pemahaman daerah penelitian yang digunakan sebagai sumber informasi awal untuk mendapatkan gambaran umum keadaan wilayah perairan dan aktivitas yang ada di dalamnya didapatkan dari 2 (dua) informan kunci. Informan kunci tersebut adalah staf Seksi Progam, Sub Dinas Perikanan pada Dinas Perikanan dan Peternakan Kabupaten Cianjur.

Pembudidaya ikan yang dijadikan responden adalah meraka yang memelihara ikan bandeng sistem KJA di perairan Waduk Cirata. Pengamatan menunjukkan bahwa kepemilikan jumlah kolam KJA berbeda antar pembudidaya dengan kisaran 1 unit ( 4 kolam) hingga 6 unit ( 24 kolam). Untuk keperiuan pengumpulan data penelitian ini dilakukan pengumpulan data per unit ( 4 kolam) untuk setiap pembudidaya yang menjadi responden. Responden yang diwawancarai merupakan informan kunci yaitu pembudidaya yang sekaligus berfungsi sebagai penyedia benih dan pembudidaya lainnya yang memelihara ikan bandeng disamping ikan mas, nila dan atau patin. Jumlah keseluruhan petani yang ada sebanyak 6 orang. Semuanya dijadikan responden.

Data yang dikumpulkan merupakan kegiatan usaha satu tahun yang lalu yaitu tahun 2002 atau 2003 sesuai dengan ketersediaan pada pembudidaya ikan. Data primer dikumpulkan pada bulan Agustus 2004. Pengolahan data dilakukan dengan cara tabulasi dan persentase yang kemudian dianalisis secara deskriptif menggunakan pendekatan metode logik. Pada metode ini data diamati dan dipilahpilah, selanjutnya hasil pembuktian dicari, dipertimbangkan, dan dianalisis untuk pengambilan kesimpulan (Nazir, 1988)

Dalam studi ini dikumpulkan juga data sekunder berbentuk bahan peraturan dan pengaturan yang berhubungan dengan usaha budidaya ikan bandeng sistem KJA di perairan Waduk Cirata. Hal ini dilaksanakan atas pertimbangan bahwa dalam menganalisis suatu kebijakan pengembangan usaha harus dimengerti peraturan dan pengaturan yang diterapkan dalam hubungannya dengan usaha budidaya ikan bandeng tersebut

Perhitungan penerimaan dan biaya produksi mengikuti kaidah anggaran masukan - hasil seperti yang dikemukakan Soekartawi et al.(1986). Nilai break event point (titik impas) dan jangka waktu pengembalian investasi diperhitungkan menurut kaidah yang dikemukakan oleh Sigit (1979) dan Gittinger (1986) yang secara sederhana dapat ditulis sebagai berikut

$$
\text { Nilai Titik Impas }=\frac{F C}{1-(V C: Y i \times P Y i)}
$$

$$
\begin{aligned}
& \text { Jangka Waktu Pengembalian } \\
& \text { Investasi }
\end{aligned}=\frac{F C+V C}{K U}
$$


Keterangan: $\mathrm{Yi}=$ Jumlah produksi

$\mathrm{PYi}=$ Harga satuan produk

$\mathrm{FC}=$ Fixed Cost (Biaya Tetap)

$\mathrm{VC}=$ Variable Cost (Biaya Variabel)

$\mathrm{KU}=$ Keuntungan Usaha

Analisis R/C bertujuan untuk melihat seberapa jauh setiap nilai rupiah yang digunakan dalam kegiatan usaha dapat memberikan sejumlah nilai penerimaan sebagai manfaatnya. Kegiatan usaha yang paling menguntungkan mempunyai nilai $\mathrm{R} / \mathrm{C}$ ratio yang terbesar (Hernanto, 1998). Menurut Soekartawi, (1995), penerimaan usaha adalah perkalian antara produksi yang diperoleh dengan harga jual yang dirumuskan dengan:

$$
\begin{aligned}
T R=Y . P y & \\
\text { Keterangan: } T R= & \text { Total penerimaan } \\
Y= & \text { Produksi yang diperoleh dalam } \\
& \text { usaha } \\
\text { Py }= & \text { Harga } Y
\end{aligned}
$$

Sedangkan total biaya merupakan penjumlahan dari biaya tetap dan biaya tidak tetap yang dirumuskan sebagai berikut:

$$
\begin{aligned}
T C=F C+V C \\
\text { Keterangan: } \begin{aligned}
T C & =\text { Total biaya } \\
F C & =\text { Total biaya tetap } \\
V C & =\text { Total biaya tidak tetap. }
\end{aligned}
\end{aligned}
$$

Pendapatan usaha tani adalah selisih antara penerimaan dan semua biaya yang dirumuskan sebagai berikut:

$$
\begin{aligned}
\mathrm{KU}=\mathrm{TR}-\mathrm{TC} & \\
\text { Keterangan: } & \mathrm{KU}=\text { Keuntungan usaha } \\
\mathrm{TR} & =\text { Total penerimaan } \\
\mathrm{TC} & =\text { Total biaya }
\end{aligned}
$$

Analisis rasio penerimaan dan biaya digunakan untuk mengetahui sejauh mana hasil yang diperoleh dari kegiatan usaha selama satu masa pemeliharaan cukup menguntungkan, dengan menggunakan rumus :

$$
\begin{aligned}
\text { RC Ratio } & =T R / T C \\
\text { Keterangan: } T R & =\text { Penerimaan usaha budidaya } \\
\text { TC } & =\text { Biaya usaha budidaya }
\end{aligned}
$$

Kriteria usaha yang digunakan adalah:

$\mathrm{R} / \mathrm{C}>1$, maka usaha untung

$\mathrm{R} / \mathrm{C}<1$, maka usaha rugi

$\mathrm{R} / \mathrm{C}=1$, maka usaha impas

\section{HASIL DAN BAHASAN}

\section{Aspek Teknis Budidaya Ikan Bandeng Sistem KJA}

Usaha budidaya ikan bandeng sistem KJA di perairan waduk pertama kali dimulai oleh seorang pengusaha sekitar awal tahun 1994. Pertama-tama usaha dilaksanakan melalui pemeliharaan nener secara sederhana dari ukuran kurang dari $1 \mathrm{~cm}$ hingga ukuran 1 inch. Nener tersebut berasal dari daerah Gresik dan atau Sungai Buntu di Cilamaya, Kabupaten Karawang. Nener diangkut menggunakan sistem tertutup dengan transportasi menggunakan mobil truk dengan kapasitas angkut 25.000 ekor per truk. Kepadatan per kantong adalah 150 ekor nener. Angka kematian nener dalam pengangkutan dari Gresik hanya sekitar $1 \%$.

Secara umum aktivitas usaha budidaya dapat dipaparkan sebagai berikut. Sebelum nener dipelihara dalam keramba, terlebih dahulu dilakukan aklimatisasi terhadap kondisi perairan waduk. Dalam proses aklimatisasi, nener ditampung dalam satu keramba waring dan diberi larutan Kalium Permanganat untuk mengobati luka yang ada akibat transportasi dan pencegahan infeksi sekunder. Setelah benih dipelihara hingga ukuran 1 inch baru dapat dibesarkan di keramba jaring apung seperti layaknya pemeliharaan ikan lainnya. Pemeliharaan nener hingga ukuran benih 1 inch memerlukan waktu sekitar 2-3 bulan. Pemeliharaan dilakukan menggunakan wadah keramba waring dan diberi pakan pelet komersil yang dihaluskan.

Usaha pemeliharaan ikan bandeng sistem KJA dilaksanakan menggunakan keramba jaring yang terbuat dari bahan poly ethylene dengan ukuran mata jaring 0,75 inch. Keramba dibentuk bujur sangkar berukuran $7 \times 7 \mathrm{~m}$ dengan kedalaman sekitar 3-5 meter. Keramba diapungkan menggunakan rakit kerangka besi berpelampung drum atau sterofoam. Pada bagian atas rakit dibuat pelataran yang dapat digunakan untuk jalan pada saat pemberian pakan atau kegiatan pemeliharaan lainnya. Ikan diberi pakan berupa pelet komersil dengan cara tebar langsung dan frekuensi 3 kali per hari pada pagi, siang dan sore hari.

Ikan nila dipelihara di luar keramba ikan bandeng yaitu di keramba bagian luar yang ukurannya sekeliling 4 buah kolam bandeng. Ikan nila yang ditebar berukuran 100 gram per ekor. Ikan nila tidak diberi pakan. Pada prinsipnya ikan nila dipelihara dengan tujuan memanfaatkan sisa pakan atau pakan yang terbuang dari keramba bandeng. Untuk jenis ikan bandeng, tingkat kematian sekitar $5 \%$ yaitu sejumlah 
125 ekor dari 2.500 ekor yang ditebar pada setiap kolam.

\section{Pemasaran Ikan Bandeng}

Berdasarkan informasi dari responden diketahui bahwa ikan bandeng bukan merupakan ikan pengganti (substitusi) bagi ikan mas, nila dan patin. Artinya, ikan mas, nila dan patin serta bandeng mempunyai pasar sendiri-sendiri, tidak ada pengaruh satu dengan lainnya dalam pemasarannya. Pemasaran ikan bandeng lebih cenderung bukan memenuhi kebutuhan ikan secara lokal di Kabupaten Cianjur seperti ikan mas dan nila. Hal ini juga tergambar dari tingginya harga ikan bandeng yang dapat mencapai Rp.10.000.per $\mathrm{kg}$ atau rata-rata sekitar Rp.8.500.- per kg dibanding dengan ikan mas dan nila yang hanya berkisar Rp.6.000.- per kg di tingkat pembudidaya ikan.

Daerah tujuan pemasaran utama ikan bandeng hasil budidaya sistem KJA di kedua waduk yang diamati adalah pasar ikan di Muara Baru (Jakarta). Ikan yang telah dipanen di tingkat pembudidaya dibeli oleh pedagang pengumpul lokal (bandar lokal). Kemudian ikan dibawa oleh bandar tersebut ke pasar ikan di Muara Baru dan dijual kepada pedagang penampung di Muara Baru yang selanjutnya dijual lagi ke pedagang pengecer di Pasar Ikan Muara Baru. Selain di pasar Muara Baru sebagian kecil ikan bandeng hasil budidaya sistem KJA juga dipasarkan ke Bandung dan Tangerang sebagai ikan konsumsi.

\section{Struktur Biaya Produksi dan Keuntungan Usaha}

Biaya produksi usaha budidaya ikan bandeng dan nila sistem KJA di perairan Waduk Cirata terdiri dari beberapa komponen yaitu biaya tetap dan tidak tetap. Biaya tetap mencakup biaya pemeliharaan rakit dan keramba serta rumah jaga dan gudang pakan. Biaya tidak tetap atau biaya operasional terdiri atas biaya pembelian benih, pakan, tenaga kerja dan lainnya selama pelaksanaan budidaya ikan berlangsung. Besaran nilai dan struktur biaya produksi usaha budidaya ikan bandeng dan nila yang dilakukan oleh pembudidaya ikan di Waduk Cirata dicantumkan pada Tabel 1.

Berdasarkan hasil perhitungan yang dikemukakan pada Tabel 1 terlihat bahwa komponen biaya produksi tertinggi pada usaha budidaya ikan bandeng dan nila sistem KJA di perairan Waduk Cirata untuk satu unit yang terdiri dari 4 keramba adalah biaya pakan yaitu mencapai $46,39 \%$ dari total biaya produksi atau mencapai Rp.12.000.000.-- selama 6 bulan. Meskipun demikian, usaha tersebut masih memberikan keuntungan usaha secara total untuk komoditas bandeng dan nila sebesar Rp.9.935.000--perperiode pemeliharaan selama 6 bulan untuk setiap unit yang terdiri dari 4 keramba. Jika dilihat hanya berdasarkan komoditas bandeng saja maka keuntungan usaha yang berasal dari komoditas ini mencapai $64,77 \%$ dari total keuntungan usaha atau sebesar Rp.6.435.000.-

Tabel 1 memperlihatkan bahwa investasi yang diperlukan untuk mengusahakan satu unit keramba jaring apung ( 4 kolam) selama 6 bulan diperlukan dana sebesar Rp.38.500.000. - Hal ini merupakan dana yang cukup besar jika seseorang pembudidaya ikan hanya seorang kepala keluarga yang mata pencaharian utamanya sebagai buruh atau nelayan. Terlihat pula bahwa $55,84 \%$ dari dana investasi tersebut merupakan modal kerja yang sebagian besar berfungsi untuk memenuhi kebutuhan pakan ikan yang dipelihara. Di lain pihak, beban bunga investasi selama 6 bulan tersebut juga cukup besar yaitu mencapai Rp.3.850.000.-

\section{Keuntungan Usaha pada Berbagai Tingkat Harga Jual likan}

Besarnya keuntungan usaha yang didapatkan pada usaha budidaya ikan bandeng dan nila sistem KJA di perairan waduk dipengaruhi oleh tingkat harga jual ikan bandeng dan nila hasil produksi budidaya tersebut. Semakin tinggi harga jual ikan bandeng dan nila tersebut semakin tinggi pula keuntungan usaha yang didapatkan oleh pembudidaya ikan selaku produsen. Namun demikian biasanya, tingkat harga produk perikanan diperkirakan akan cenderung menurun akibat pengaruh berbagai faktor antara lain kuantitas ikan hasil produksi pembudidaya lainnya untuk jenis ikan mas, nila dan patin.

Pada Tabel 2 dikemukakan tingkat keuntungan usaha budidaya ikan bandeng dan nila sistem K.JA yang diperoleh berdasarkan perhitungan beberapa tingkat harga jual ikan bandeng dan nila hasil produksi sistem KJA tersebut sedangkan harga dan jumlah faktor produksi lainnya diasumsikan tidak berubah. Berdasarkan hasil perhitungan yang dikemukakan pada Tabel 2 terlihat bahwa jika tingkat harga jual ikan bandeng dan nila hasil produksi budidaya sistem KJA mencapai Rp.5.500.- per kg maka usaha budidaya pembesaran ikan bandeng dan nila sistem KJA di perairan Waduk Cirata ini mengalami kerugian sebesar Rp.1.465.000.- per periode pemeliharaan selama 6 bulan per unit KJA. Sementara ini harga ikan bandeng yang pernah turun hingga mencapai Rp.6.500.- per $\mathrm{kg}$ masih memberikan keuntungan bagi pemelihara ikan tersebut sebesar Rp.2.335.000 - selama 6 bulan atau rata-rata hanya sebesar Rp.389.165.-per bulan. 
Tabel 1. Struktur biaya produksi usaha budidaya ikan bandeng dan nila sistem KJA di perairan Waduk Cirata, Jawa Barat, 2004 (satu unit selama 6 bulan)

Table 1. Production cost structure of milkfish and tilapia culture in floating net cage system at Cirata Reservoir, West Java 2004 (1 unit during 6 months)

\begin{tabular}{|c|c|c|}
\hline Uraian/ltem & $\begin{array}{l}\text { Nilai/Value } \\
\text { (Rupiah) }\end{array}$ & $\begin{array}{l}\text { Persentase/ } \\
\text { Percentage }\end{array}$ \\
\hline A. Investasi/lnvesment & 38.500 .000 & 100 \\
\hline $\begin{array}{l}\text { - Konstruksi rakit pengapung untuk kapasitas } 4 \text { keramba jaring } \\
\text { apung ( } 4 \text { kolam })+ \text { rumah jaga/Floating construction for } 4 \text { cages } \\
\text { and guard house }\end{array}$ & 10.000 .000 & 25.98 \\
\hline - Keramba jaring apung 4 buah/4 floating net cages & 3.000 .000 & 7.79 \\
\hline $\begin{array}{l}\text { - Keramba jaring ganda } 1 \text { unit (jaring besar)/Double net cage } 1 \text { unit } \\
\text { (big size of net cage) }\end{array}$ & 4.000 .000 & 10.39 \\
\hline - Modal kerja/Working capital & 21.500 .000 & 55.84 \\
\hline B. Biaya tetap/Fixed cost & 4.365 .000 & 16.88 \\
\hline $\begin{array}{l}\text { - Penyusutan/rehab rakit pengapung, keramba dan rumah jaga } \\
\text { selama } 6 \text { bulan/Depreciation of floating construction for } 6 \text { months }\end{array}$ & 500.000 & 1.93 \\
\hline $\begin{array}{l}\text { - Biaya keamanan selama } 6 \text { bulan } \times \text { Rp. } 2.500 / \text { Security cost during } 6 \\
\text { months }\end{array}$ & 15.000 & 0.06 \\
\hline $\begin{array}{l}\text { - Bunga investasi selama } 6 \text { bulan ( } 20 \% \text { per tahun)//nterest of } \\
\text { invesment for } 6 \text { months }\end{array}$ & 3.850 .000 & 14.89 \\
\hline C. Biaya variabel/Variable cost & 21.500 .000 & 83.12 \\
\hline $\begin{array}{l}\text { - Benih ikan bandeng } 10.000 \text { ekor } \times \text { Rp.650/10.000 Milkfish fry } \times \text { Rp } \\
650\end{array}$ & 6.500 .000 & 25.13 \\
\hline $\begin{array}{l}\text { - Benih ikan nila } 200 \mathrm{~kg} \times \mathrm{Rp} .12 .000 / 200 \mathrm{~kg} \text { Tilapia fry } \\
\text { x Rp } 12000\end{array}$ & 2.400 .000 & 9.28 \\
\hline $\begin{array}{l}\text { - Pakan berupa pelet komersil } 4.000 \mathrm{~kg} \times \mathrm{Rp} .3 .000 \mathrm{per} \mathrm{kg} / \\
4.000 \mathrm{~kg} \text { commercial feed } \times \mathrm{Rp} 3.000\end{array}$ & 12.000 .000 & 46.39 \\
\hline $\begin{array}{l}\text { - Tenaga kerja } 1 \text { orang selama } 6 \text { bulan } x \\
\text { Rp. } 100.000 .- \text { /Labour cost }\end{array}$ & 600.000 & 2.32 \\
\hline D. Total biaya produksi $(B+C) /$ Total of production cost $(B+C)$ & 25.865 .000 & 100 \\
\hline $\begin{array}{l}\text { E. Produksi ikan bandeng ( } 4 \text { kolam; ukuran rata-rata } 4 \text { ekor per } \\
\mathrm{kg}) 4 \times 950 \mathrm{~kg} \times \mathrm{Rp} .8 .500 .- \text { per } \mathrm{kg} / \mathrm{Value} \text { of milkfish } \\
\text { production (4 cages with an average of } 4 \mathrm{pc} / \mathrm{kg} \text { ) }\end{array}$ & 32.300 .000 & 90.22 \\
\hline $\begin{array}{l}\text { F. Produksi ikan nila (jaring besar)/Value of tilapia production } \\
1.000 \mathrm{~kg} \times R \text { R.3.500.- }\end{array}$ & 3.500 .000 & 9.78 \\
\hline G. Nilai produksi total/Total revenue $(E+F)$ & 35.800 .000 & 100.00 \\
\hline H. Keuntungan usaha total/Total profit $(G-D)$ & 9.935 .000 & 100.00 \\
\hline $\begin{array}{l}\text { I. Keuntungan usaha dari bandeng/Profit from milkfish culture } \\
(E-D)\end{array}$ & 6.435 .000 & 64.77 \\
\hline
\end{tabular}

Keterangan/Note: Penyusutan diperhitungkan untuk satu unit selama 6 bulan/Depreciation accounted for one unit for 6 months

Nilai ini menggambarkan bahwa dengan harga ikan bandeng tersebut, usaha ini tidak baik opportunity-nya jika dibandingkan nilai investasi yang ditanamkan disimpan di bank yang minimal akan menghasilkan bunga $1 \%$ dari Rp.38.500.000.- atau sebesar Rp.385.000.- tanpa harus bekerja dan tanpa menghadapi resiko gagal panen.

\section{Nilai Titik Impas}

Nilai titik impas adalah nilai yang menjelaskan saat dimana usaha budidaya ikan bandeng dan nila sistem KJA di Waduk Cirata tidak mendatangkan keuntungan tetapi tidak mengalami kerugian. Nilai ini akan berbeda pada berbagai tingkat harga jual ikan 
Tabel2. Tingkat keuntungan usaha budidaya ikan bandeng sistem KJA pada berbagai tingkat harga jual ikan hasil produksi di Waduk Cirata, Jawa Barat, 2004 (satu unit/6 bulan)

Table 2. Profit of milkfish culture in floating net cage system based on various price of milkfish production at Cirata Reservoir, West Java, 2004 (one unit/6 months)

\begin{tabular}{ccc}
\hline $\begin{array}{c}\text { Harga jual ikan bandeng/ } \\
\text { Price of milkfish sold } \\
\text { (Rp/Kg) }\end{array}$ & $\begin{array}{c}\text { Total nilai produksi/Total } \\
\text { value of fish production } \\
\text { (Rupiah) }\end{array}$ & $\begin{array}{c}\text { Total ke untungan usahal } \\
\text { Total of profit } \\
\text { (Rupiah) }\end{array}$ \\
\hline 10.000 & 41.500 .000 & 15.635 .000 \\
9.500 & 39.600 .000 & 13.375 .000 \\
9.000 & 37.700 .000 & 11.835 .000 \\
8.500 & 35.800 .000 & 9.935 .000 \\
8.000 & 33.900 .000 & 8.035 .000 \\
7.500 & 32.000 .000 & 6.135 .000 \\
7.000 & 30.100 .000 & 4.235 .000 \\
6.500 & 28.200 .000 & 2.335 .000 \\
6.000 & 26.300 .000 & 435.000 \\
5.500 & 24.400 .000 & -1.465 .000 \\
\hline
\end{tabular}

Keterangan/Note: Total keuntungan usaha diperhitungkan dari perubahan harga ikan bandeng saja, sedangkan ikan nila tetap/Total profit milkfish culture is accounted from changes of milkfish price, remain to tilapia

bandeng dan nila hasil produksi di KJA tersebut yang dikemukakan pada Tabel 3. Berdasarkan hasil perhitungan yang dikemukakan pada Tabel 3 terlihat bahwa usaha budidaya ikan bandeng dan nila sistem KJA yang berlangsung saat ini mencapai titik impas pada saat produksi ikan mencapai $1.283,82 \mathrm{~kg}$ dengan nilai Rp.10.912.500.-. Namun demikian, jika harga ikan bandeng dan nila menurun hingga Rp.6.000 - per kg maka usaha budidaya pembesaran ikan bandeng dan nila sistem KJA di perairan Waduk Cirata ini mengalami kerugian.

\section{Jangka Waktu Pengembalian Investasi}

Jangka waktu pengembalian investasi untuk masing-masing tingkat harga jual ikan bandeng sistem KJA di Waduk Cirata dicantumkan pada Tabel 4.

Berdasarkan hasil perhitungan yang dikemukakan pada Tabel 4 terlihat bahwa jangka waktu pengembalian investasi yang dicapai usaha budidaya KJA saat ini adalah pada tingkat harga jual Rp.8.500.per kg selama 3 periode pemeliharaan atau selama 18 bulan. Namun jika tingkat harga jual ikan bandeng hasil produksi budidaya sistem KJA mencapai Rp.6.500.- per kg maka usaha budidaya pembesaran ikan bandeng sistem KJA di perairan Waduk Cirata ini akan mengembalikan investasi yang ditanamkan dalam jangka waktu yang lama yaitu mencapai 72 bulan atau selama 6 tahun.

\section{Permasalahan dan Prospek Pengembangan Budidaya Ikan Bandeng}

Permasalahan merupakan hal yang menghambat usaha budidaya ikan bandeng sistem KJA di waduk baik yang dapat diselesaikan ataupun tidak dapat diselesaikan oleh pembudidaya ikan baik secara perorangan maupun berkelompok. Dalam hubungannya dengan budidaya ikan bandeng sistem KJA di perairan Waduk Cirata, permasalahan utama yang dialami pembudidaya adalah permodalan. Permodalan yang dibutuhkan dalam pemeliharaan ikan bandeng sebanyak 1 unit saja memerlukan investasi sebesar Rp.38.500.000.-. Nilai investasi sebesar ini tidak dapat diselesaikan oleh pembudidaya sendiri secara perorangan dengan segala keterbatasannya untuk akses terhadap lembaga perbankan. Untuk itu, budidaya ikan bandeng sistem KJA seyogyanya dilaksanakan oleh pengusaha yang mempunyai modal besar, bukan oleh pembudidaya yang saat ini lebih banyak berfungsi sebagai tenaga kerja saja dalam budidaya ikan di perairan waduk ini.

Kemudian, permasalahan yang juga dirasakan pembudidaya adalah mahalnya harga benih yang mahal yaitu mencapai Rp.650.- per ekor. Harga benih yang murah dengan ukuran yang lebih kecil tidak dapat diyakini oleh pembudidaya dapat dipelihara hingga ukuran yang lebih besar. Hal ini berhubungan dengan perlunya proses aklimatisasi benih yang saat ini hanya dilakukan penyedia benih secara 
Tabel 3. Nilai titik impas usaha budidaya ikan bandeng sistem KJA di Perairan Waduk Cirata pada berbagai tingkat harga jual ikan hasil produksi di Waduk Cirata, Jawa Barat, 2004 (satu unit/6 bulan)

Table 3. Break event point of milkfish culture in floating cage system at Cirata Reservoir based on various price of milkfish at Cirata Reservoir, West Java, 2004 (one unit/6 months)

\begin{tabular}{cccc}
\hline \multirow{2}{*}{$\begin{array}{c}\text { Harga jual ikan } \\
\text { bandeng/Price } \\
\text { of milkfish sold } \\
\text { (Rp/Kg) }\end{array}$} & $\begin{array}{c}\text { Total nilai produksi/ } \\
\text { Total value of fish } \\
\text { production }\end{array}$ & \multicolumn{2}{c}{$\begin{array}{c}\text { Nilai titik impas/ } \\
\text { Break event point }\end{array}$} \\
\cline { 2 - 4 } & Rupiah & Rupiah & $\mathrm{Kg}$ \\
\hline 10.000 & 41.500 .000 & 9.056 .015 & 905,60 \\
9.500 & 39.600 .000 & 9.551 .420 & $1.005,41$ \\
9.000 & 37.700 .000 & 10.151 .160 & $1.127,90$ \\
8.500 & 35.800 .000 & 10.912 .500 & $1.283,82$ \\
8.000 & 33.900 .000 & 11.926 .230 & $1.490,78$ \\
7.500 & 32.000 .000 & 13.227 .270 & $1.763,64$ \\
7.000 & 30.100 .000 & 15.051 .720 & $2.150,25$ \\
6.500 & 28.200 .000 & 18.187 .500 & $2.798,08$ \\
6.000 & 26.300 .000 & 23.852 .460 & $3.975,41$ \\
\hline
\end{tabular}

Tabel 4. Jangka waktu pengembalian investasi dalam usaha budidaya ikan bandeng sistem KJA di Waduk Cirata pada berbagai tingkat harga jual ikan bandeng hasil produksi di Waduk Cirata, Jawa Barat, 2004 (satu unit/6 bulan)

Table 4. Payback period of milkfish culture in floating cage system at Cirata Reservoir based on various price of milkfish at Cirata Reservoir, West Java, 2004 (one unit/6 months)

\begin{tabular}{|c|c|c|c|c|c|}
\hline \multirow{3}{*}{$\begin{array}{c}\text { Harga jual ikan } \\
\text { bandeng/Price of } \\
\begin{array}{c}\text { milkfish sold } \\
\text { (Rp/Kg) }\end{array} \\
10.000\end{array}$} & \multirow{3}{*}{$\begin{array}{c}\text { Total keuntungan } \\
\text { usaha/Total profit } \\
\text { (Rupiah) }\end{array}$} & \multicolumn{4}{|c|}{$\begin{array}{c}\text { Jangka waktu pengembalian investasi/ } \\
\text { Payback period }\end{array}$} \\
\hline & & \multicolumn{2}{|c|}{$\begin{array}{c}\text { Periode } \\
\text { pemeliharaan/ } \\
\text { Period of culture }{ }^{\star} \text { ) }\end{array}$} & \multicolumn{2}{|c|}{$\begin{array}{c}\text { Lama waktu } \\
\text { pemeliharaan/Duration } \\
\text { (Bulan/Months) }\end{array}$} \\
\hline & & 1.65 & $(2)^{\star \star}$ & 10.0 & 12 \\
\hline 9.500 & 13.375 .000 & 1.93 & (2) & 11.6 & 12 \\
\hline 9.000 & 11.835 .000 & 2.19 & (3) & 13.1 & 18 \\
\hline 8.500 & 9.935 .000 & 2.60 & (3) & 15.6 & 18 \\
\hline 8.000 & 8.035 .000 & 3.22 & (4) & 19.3 & 24 \\
\hline 7.500 & 6.135 .000 & 4.21 & (5) & 25.3 & 30 \\
\hline 7.000 & 4.235 .000 & 6.11 & (7) & 36.6 & 42 \\
\hline 6.500 & 2.335 .000 & 11.08 & (12) & 66.5 & 72 \\
\hline
\end{tabular}

Keterangan/Note: *) Satu periode pemeliharaan adalah 6 bulan/One period of culture is 6 months **) Angka dalam kurung merupakan pembulatan/Value in brackets is rounding of periode of culture 
perorangan, bukan disediakan oleh balai benih ikan terdekat. Oleh karena itu penyediaan benih ikan bandeng yang diperlukan untuk budidaya di KJA di perairan Waduk Cirata ini sangat tergantung dari adanya suplai benih dari lokasi yang jauh terutama dari Sungai Buntu (Karawang) atau dari Gresik (Jawa Timur). Dalam hal ini, kendala kiranya dapat saja diatasi Dinas Perikanan setempat melalui balai benih ikan terdekat.

Pembudidaya ikan mengemukakan bahwa permasalahan lainnya yang mereka hadapi adalah kurangnya pembinaan dari kelembagaan yang berwenang baik dalam hal teknis budidaya maupun kelembagaan pemasaran yang menunjang usaha budidaya tersebut. Kelembagaan lainnya yang tersedia di wilayah ini seperti penyedia pakan tidak mau menyediakan pakannya untuk digunakan terlebih dahulu oleh pembudidaya dengan perjanjian dibayar setelah panen seperti halnya pada pembudidaya ikan mas, nila dan patin. Pembudidaya ikan bandeng mengemukakan bahwa, keengganan penyedia pakan dalam hal ini antara lain karena lamanya waktu yang diperlukan dalam pemeliharaan ikan bandeng dan nila yang mencapai 6 bulan, sedangkan ikan lainnya seperti mas dan nila hanya perlu waktu 3 bulan.

Permasalahan-permasalahan yang dihadapi pembudidaya ikan bandeng dan nila sistem KJA tersebut di atas pada akhirnya menunjukkan bahwa usaha budidaya ikan bandeng dan nila selama satu dekade terakhir ini cenderung mengalami kemunduran. Di lapangan terlihat bahwa pembudidaya yang mengusahakan budidaya ikan bandeng dan nila ini semakin menurun jumlahnya dan hingga tahun 2004 hanya tersisa beberapa orang saja. Bahkan pembudidaya ikan bandeng yang ada saat ini pun tidak hanya mengusahakan ikan bandeng saja tetapi juga memelihara ikan mas dan nila. Ikan bandeng hanya berfungsi sebagai pelengkap saja bagi ikan mas dan nila kecuali pada seorang pengusaha yang saat ini juga berfungsi sebagai pensuplai benih ikan bandeng. Pengusaha inipun tampaknya sudah menunjukkan gejala yang tidak serius dalam usaha budidaya ikan bandeng. Dengan demikian dapat dikemukakan bahwa pada dasarnya ditinjau dari segi finansial, usaha budidaya ikan bandeng sistem KJA di perairan Waduk Cirata ini layak untuk dikembangkan meskipun diperlukan investasi yang cukup besar.

\section{KESIMPULAN DAN SARAN}

1. ikan bandeng bukan merupakan ikan pengganti (substitusi) bagi ikan mas, nila dan patin. Pernasaran ikan bandeng lebih cenderung bukan memenuhi kebutuhan ikan secara lokal di Kabupaten Cianjur seperti ikan mas dan nila.

2. Secara finansial, usaha budidaya ikan bandeng sistem KJA di perairan Waduk Cirata layak untuk dikembangkan. Dalam hubungannya dengan budidaya ikan bandeng sistem KJA di perairan Waduk Cirata, permasalahan utama yang dialami pembudidaya adalah permodalan, dan menghadapi permasalahan mahalnya harga benih serta kurangnya pembinaan kelembagaan khususnya pemasaran dan penyediaan benih.

3. Usaha budidaya ikan bandeng sistem KJA seyogyanya dilaksanakan oleh pengusaha yang mempunyai modal besar, bukan oleh pembudidaya yang saat ini lebih banyak berfungsi sebagai tenaga kerja saja dalam budidaya ikan di perairan waduk ini. Dalam hal ini, sejalan dengan pengembangan usaha budidaya tersebut, diperlukan peran pemerintah daerah terutama dalam penyediaan benih dan fasilitasi kelembagaan pemasaran dan permodalan.

\section{DAFTAR PUSTAKA}

Gittinger, J.P., 1986. Analisa Ekonomi Proyek-Proyek Pertanian. Penerbit Universitas Indonesia. Jakarta. $579 \mathrm{pp}$.

Hernanto, F., 1998. IImu Usahatani. Penerbit Penebar Swadaya. Jakarta. $187 \mathrm{pp}$

Kartamiharja, E.S. 1995, Daya Dukung Perairan dan Pengembangan Budidaya Ikan Dalam Keramba Jaring Apung yang Ramah Lingkungan. Prosiding Expose Budidaya Ikan dalam KJA yang Ramah Lingkungan. Balai Penelitian Perikanan Air Tawar. Sukamandi. Jawa Barat. p.13-22

Krismono dan Krismono, A. 1998. Mengapa Ikan Dalam Keramba Jaring Apung di Danau dan Waduk Mati? Warta Penelitian Perikanan Indonesia. Puslitbang Perikanan. Badan Litbang Pertanian. Departemen Pertanian. p. 12-16

Nasution, Z., 1999. Pengelolaan Limbah Pakan Ikan di Perairan Waduk; Tinjauan Aspek Ekonomi dan Lingkungan. Prosiding Semiloka Nasional Pemanfaatan dan Pengelolaan Perairan Waduk dan Danau. Kerjasama Kantor Meneg. KL.H, Depdagri dan PPLH IPB. Bogor. 7 pp.

Nazir, M., 1988, Metode Penelitian, Ghalia Indonesia, Jakarta. $622 \mathrm{pp}$

Sarnita, A., 1986. Perairan Umum di Indonesia Sebagai Salah Satu Sumber Daya Alam. Prosiding Puslitbangkan No. 6/SPPU/1986. Badan Litbang Pertanian. Departemen Pertanian. p. 17-31

Sigit, S., 1979. Analisa Break Even. Penerbit Pendidikan Ahli Administrasi Perusahaan. Universitas Gajah Mada. Yogyakarta. $67 \mathrm{pp}$

Soekartawi, A., Soehadjo, Dillon, J.L. dan Hardaker, J.B.,1986. Ilmu Usahatani dan Penelitian Untuk 
Pengembangan Petani Kecil. Penerbit Universitas Soekanwati, 1995. Analisis Usahatani. Universitas IndoIndonesia. Jakarta. $162 \mathrm{pp}$. nesia Press. Jakarta. $110 \mathrm{pp}$. 
